\title{
A Conceptual Framework to Measure Brand Equity in Indian Banking \& Financial Services Firms
}

\author{
Debabrata Das \\ (Department of Business Administration, Bengal School of Technology \& Management, India)
}

\begin{abstract}
Many business entities have attached utmost importance to managing brand equity in prevalent competitive scenario \& Indian banking and financial services firms are no exceptions. Research on services marketing indicates that customer satisfaction has a positive direct effect on brand equity and that is why the customer based brand equity concept has become most popular among all the brand equity measures, because this concept acknowledges that the power of a brand resides in the minds of the customers. Researchers also believe that the extended Ps of services marketing may influence customer satisfaction. Recent empirical study has identified key factors of the 3Ps of services marketing, through which customer satisfaction can be determined and measured in case of banking and financial services firms. This paper represents a conceptual framework through which customer based brand equity can be measured using the identified key factors of 3Ps.So this framework can be used as the theoretical base to construct and develop a scale for quantitative measurement of brand equity for Indian banking and financial services firms in future.
\end{abstract}

Keywords - Brand Equity, Conceptual Framework for Brand Equity measurement, Customer Based Brand Equity, Extended Ps of Services Marketing.

\section{INTRODUCTION}

With growing stress on product or service differentiation in the face of stiff competition, brand management has taken the centre stage in firms' strategic planning agenda in liberalized corporate India. Since the concept of brand equity began gaining widespread attention in the 1980s, many different methods of defining and measuring brand equity have been conceptualized. Researchers mainly embrace the task of defining the term brand equity exclusively from either the perspective of the consumer or the firm. Keller and Lehmann divide brand equity measures into three categories: customer mindset, product market outcome, and financial outcome measures [1]. The first category of measurement i.e. measuring brand equity from customers' perspective by taking in to consideration the impact of the brand on customer mindset have become very popular throughout the world. Keller and Lehmann consider brand equity measurement in terms of customer mindset which should include "everything that exists in the minds of customers with respect to a brand (e.g. thoughts, feelings, experiences, images, perceptions, beliefs, and attitudes)" [1].This aspect of brand equity measurement encompasses a wide variety of both quantitative and qualitative measures. Such measures of consumer-based brand equity (CBBE) have received considerable attention among the researchers and academia and significant contribution has been made in this regard in the literature ([2],[3],[4],[5],[6],[7]).In this paper a rather different approach has been taken to develop a conceptual framework for customer based brand equity (CBBE) measurement in Indian banking sector. Four sequential theoretical linkages have been made by extensive literature review with the sole objective of converging and integrating the ideas and concepts developed regarding brand equity measures over the years by the researchers. At the final stage the result of this convergent approach has been linked with the inference of recent empirical study regarding customer satisfaction in Indian banking sector to develop a conceptual model for measuring CBBE for Indian banking sector.

\section{THEORETICAL LINKAGE I}

First major and significant work in the field of measuring brand equity from customers' mindset has been done by Keller[4].Keller viewed the concept of brand equity from the perspective of the consumer basing his approach on customer knowledge of a brand, familiarity with the brand and associations with the brand. According to this approach customers' brand knowledge can be expressed as a sum of brand awareness and brand image. Keller's conceptualization of brand image is considered a perception about a brand as reflected by the brand associations held in consumers' memory. He suggested that "brand associations" comprise of brand attributes, brand benefits, and overall brand attitudes .Within brand awareness there are two variables: brand recall and brand recognition. While, within brand image there are variables such as brand association, brand attitude, brand quality, brand attachment, and brand activity. From the research of Keller, Keller \& Lehman five dimensions have emerged which are highlighted in Consumer Based Brand Equity (CBBE) Model as particularly important measures of customers' mind set: 
[1]. Brand Awareness: The extent and ease with which customers recall and recognize the brand and can identify the products and services with which it is associated. Brand awareness is also known as brand familiarity ([9], [10]).

[2]. Brand Associations: The strength, favourability and uniqueness of perceived attributes and benefits for the brand. Brand associations often represent key sources of brand value, because they are the means by which consumers feel how brands satisfy their needs.

[3].Brand Attitudes: Overall evaluations of the brand in terms of its quality and the satisfaction it generates.

[4]. Brand Attachment: The degree of loyalty the customers feel toward the brand. A strong form of attachment and adherence is the customers' resistance to change and the ability of a brand to withstand bad news like a product or services failure. In the extreme, the attachment can become addiction.

[5]. Brand Activity: The extent to which the customers use the brand, talk to others about the brand, seek out brand information, promotions, events, and so on ([1], [5], [8]).

Keller considers these five dimensions from the perspective of values and he believes an obvious hierarchy exists in these five dimensions in terms of value. Awareness supports associations, which drives attitudes that lead to attachment and activity. Brand value is created at this stage when customers have (1) deep, broad brand awareness (2) appropriately strong, favourable and unique points of parity and points of difference (3) positive brand judgments and feelings (4) intense brand attachment and loyalty and (5) a high degree of brand activity [8]. Again Aaker suggests that brand image is equivalent to brand associations [2]. So all the components of brand image can be represented by the brand associations and thus Brand Attitudes, Brand Attachment, Brand Activity can be directly linked with brand association and only brand associations can represent Brand Attitudes, Brand Attachment, and Brand Activity. Thus CBBE Model can be represented as having only two components i.e. Brand Awareness and Brand Associations.

\section{THEORETICAL LINKAGE II}

Researchers have attempted to develop brand equity constructs particularly for services sector for quite some times and Berry's contribution in this regard is significant. Berry believes that there are six key construct of services brand management i.e. company's presented brand, external brand communications, customer experiences, brand awareness, brand meaning and brand equity and he depicts the inter relationship among these six key constructs in his model[11].The company's presented brand is the company's brand message or the controlled communication of the company's identity or purpose what the firm intends to communicate to its prospective as well as existing customers. The presented brand directly influences the brand awareness of the customers. The brand meaning is the customers' perceptions about the brand in terms of the experiences with the services of the firm and that is why customers' actual experiences before subscribing to the services, during the service encounter and after the purchase of the services have direct and primary impact on brand meaning. On the other hand external brand communication means the word of mouth communication that contains the actual experience descriptions of the existing customers about the brand and it spreads from existing customers to the new and prospective customers. As existing customer's service experiences influence the external brand communications, it in turn influences brand awareness and thus brand equity.

From Berry's conceptualisation of the brand equity model for the services firms, it can be said that the customer experiences impact both the brand awareness and the brand meaning. According to Berry, as both brand awareness and brand meaning influence the brand equity, the greatest influencing factor of brand equity is the customers' actual experiences of the services with which the brand is attached[11].Services marketing researchers have established the linkage and correlation as well as convergence of Berry's and Keller's model and it can be inferred that Brand meaning in Berry' model is equivalent to brand image in Keller's model ([11],[12],[13],[14]).

In the final construct of the theoretical linkage I, it has been concluded that in customer based brand equity measures there are two components i.e. brand awareness and brand associations. Again according to Aaker brand image is equivalent to brand associations. So it can be said that brand meaning and brand awareness are the two main influencing factors of brand equity in services sector [2]. Thus in CBBE model for services firms, brand meaning in terms of customer experiences and the brand awareness should be the two deciding components. 


\section{THEORETICAL LINKAGE III}

Berry's conceptualization of brand equity model for services sector has two components of brand equity i.e. brand awareness and brand meaning [11]. According to Ghazizadeh et al., Berry identifies a total of eight factors related with various aspects of banking operations and services to define brand meaning and as brand meaning is influenced by the customer's experience with the organization, these factors will be the key factors in representing customers' experiences with banks [15]. These factors are as follows:

\section{[1].Service Operation}

Due to the process driven and interactive nature of the banking services, different components of service quality dimensions such as assurance, responsiveness and empathy must be the part of the customers' experience [15]. According to Ghazizadeh et al., researchers like Berry, Anderson and O'Cass et al. believe that customers' trust, satisfaction and loyalty depends on these service quality dimensions of service operation ([12], [15], [16], [17]).

\section{[2].Employees.}

All human beings who play a part in the process of creating, delivering and managing services will come under employees. Ghazizadeh et al. supported the observation of researchers like L.de Chernatony, M. J. Bitner, according to whom, the customers' evaluation of service performance and customers' satisfaction perception of service quality depend on the customer - employee interaction and the customer-employee relationship ([15], [18], [19]).

\section{[3].Environment.}

Environment is actually a component of physical evidence. Physical evidence represents the environment in which the service is delivered and where the interaction between the firm and the customer takes place and any tangible components that facilitate performance or communication of the service [20].M. J. Bitner also stresses on developing the physical environments associated with the service delivery process in order to ensure highly perceived service quality and perceived satisfaction in the customers' minds ([15], [19]).

\section{[4]. Features.}

L.de Chernatony et al believe that number of branches, ease of access, use of technology, convenience process employed in banking services delivery play an important part in brand building in case of banking and financial services([15],[18]).

\section{[5]. Perceived Fees Value.}

According to Ghazizadeh et al. researchers like Padgett and Douglas identify services pricing as an important factor in brand image evaluation because service prices, in fact, is important in service choice decision making ([15], [21]).

\section{[6].Self-Brand Image.}

Padgett and Douglas also believe that the attributes, functional consequences and symbolic brand meanings associated with a service provider help to create a positive image into the mind of the customers and also help in brand positioning([15],[21]).

\section{[7]. Brand Aroused Feelings.}

While commenting on brand aroused feelings, Ghazizadeh et al. strongly supported the previous research conducted by Richins, Boles et al., Arora et al ([15],[22],[23],[24]). Richins believes that emotional variables like feelings is important in purchase decision making and plays an important role in effecting customers' reactions [22]. Boles et al strongly agree with this and they declare that feelings aroused in a service delivery environment affect purchase intention and create brand related perception in customers' mind[23]. Research by Arora et al stresses on emotional values or feeling as more sustainable than functional values in case of banking services [24].

\section{[8]. Brand Personality.}

Berry defines brand personality as the set of human characteristics associated with a brand [12].Siguaw et al. believe that a well established brand personality increases emotional ties with the brand and it also increases brand preference and brand patronage thus ultimately helps in building customers' trust and ensuring customers' loyalty [25].

From theoretical linkage II, it can be said that in case of CBBE model for services firms, Brand Meaning in terms of customer experiences and the Brand Awareness should be the two deciding components. Now as 
Berry's conceptualisation of brand equity model for banking services sector has eight factors which represent customer experiences, it can be inferred that CBBE model for banking services firms should have two components i.e. Brand Awareness and customers' experience in terms of the eight factors mentioned in Berry's model [12].

\section{THEORETICAL LINKAGE IV}

From theoretical linkage III, it can be inferred that CBBE model for banking services firms should have two components i.e. Brand Awareness and customers' experience in terms of the eight factors mentioned in Berry's model [12]. Now these factors are Service Operation, Employees, Environment, Features, Perceived Fees Value, Self-Brand Image, Brand Aroused Feelings and Brand Personality.

Among these eight factors, one of the most important factors is Self Brand Image. According to Keller's (1993) conceptualization of brand image, it is a perception about a brand as reflected by the brand associations held in consumers' mind [4].Again as per the original belief of Padgett and Douglas and as per the support for this belief by Ghazizadeh et the attributes, functional consequences and symbolic brand meanings associated with a service provider actually create a brand image into the minds of the customers([15],[21]), it can be rightly inferred that all the other seven factors will play the role of creating brand image into the customers' mind and that is why the self brand image factor can be embedded within the other seven factors and so only seven factors will be sufficient to capture customers' service experiences.

Again among these seven factors the Perceived Fees Value factor is not very important in Indian context. This factor denotes the importance of services pricing and fees associated with services delivery in banking sector. In India, as RBI regulates the interest rates, individual banks have little control over these issues. Though recently some flexibility and deregulation have taken place in Indian banking sector, interest rates and fees associated with service delivery should not be termed as a differentiating factor in Indian scenario. So, for the sake of convenience and simplicity, the perceived fees value factor can be ignored from the current discussion.

Now among the six factors, brand personality is of particular importance. Pioneering research by Aaker suggests that consumers perceive brands as having five distinct personality dimensions and these are Sincerity, Excitement, Competence, Sophistication, and Ruggedness [26]. Based on these dimensions brand personality measurement scales have been developed using the traits associated with these dimensions. The identified traits associated with these dimensions are down to earth, honest, wholesome, and cheerful (in case of Sincerity); daring, spirited, imaginative, up to date ( in case of Excitement); reliable, intelligent, successful ( in case of Competence); upper class , charming ( in case of Sophistication );outdoorsy, tough( in case of Ruggedness).Aaker also believes that brand personalities are formed in two different ways: through personrelated attributes and product feature-related attributes[26]. In case of person-related attributes, the perceived personality traits of people associated with a brand have been used to describe the brand's personality; on the other hand in case of product-feature-related attributes, the attributes are derived from consumers' personal experiences while using the brand, product category associations and any other associations induced by the brand name, symbol or logo, the advertising style, the price, and the distribution channel. Researchers argue on the issue of universal applicability of Aaker's brand personality scale and some of them even question the way of depicting brand personality by five dimensions. Based on empirical study researchers found that the judgmental processes involving the brand-related judgments are actually different from those in human personality impression formation and that is why the Aaker's view that brand personality is similar to human personality can be challenged [27].Recent empirical study in India shows that all of the items of Aaker's Brand Personality Scale may not be applicable in the Indian situation [28].

Another way of depicting brand personality in services branding is to looking into the areas where it is relevant. According to Ghantous brand personality can be relevant to service branding in four main areas i.e. relations, emotions, values and differentiation [29].In services marketing building strong and enduring relationship with the customers is important for ensuring long terms customer loyalty and repeat purchases by the customers. In this regard it can be said that brand personality is often presented as a prerequisite for developing consumer-brand relationships. Ghantous supports the belief of the researchers like de Chernatony et al. and Dall'Olmo Riley et al. who consider service brands as relation based and relationship builder ([29],[30],[31]). So brand personality can be depicted as an instrument for building relationship with customers or brand personality can be termed as a relationship marketing tool in case of services marketing.

The role of emotional aspects of services is very important in services marketing. Berry considers that in a services marketing situation, the marketer should not only cater to the functional needs of the customers but also should address the emotional needs of the customers [12]. Morrison and Crane believe creating and managing an emotional experience before, during and after service delivery is important in building a strong service brand [32]. Ghantous agree with both Berry and Morrison and Crane [29].As marketing is all about delivering values to the customers, delivering values is particularly important in services marketing due to the 
intangible nature of services. In this regard the remarks of researchers like Edvardsson et al. and de Chernatony is worth mentioning.

Edvardsson et al. (cited by Ghantous, 2008) believe that service marketers should not only concentrate on delivering and adding values to the customers but also on communicating the core values of the organization to the stakeholders through the services delivery[33]. Researchers like de Chernatony and Segal-Horn (cited by Ghantous, 2008) consider that the core values of a service firm can be communicated to the customers through brand personality [34]. Researcher like Ghantous supports their views [29].

The final area where brand personality is very relevant in case of services sector is differentiation. In this era of high competitiveness, services brands must offer unique and distinguishable differentiation through brand personality in order to be more visible into the minds of the customers. Therefore, brand personality can be represented as a component of brand equity which can highly differentiate the service brand, communicate the core values of the firm and its services internally and externally, build and maintain emotional bonds with consumers and help the consumer-brand relationships to develop [29].

Now it is very important to revisit the concept of customer satisfaction in services sector to focus on the relationship between brand personality and customer satisfaction. Besides the direct impact of personality perceptions on satisfaction, previous research suggests that brand personality can affect consumer's satisfaction through the congruence he/she perceives between his/her personality and that of the brand [29].

Kim et al consider that proper branding reduces customers' risk feeling during buying the services, a high level brand personality enhances customers' satisfaction and loyalty [35]. In this relation, the result of a recent empirical study should be highlighted. The study was conducted to find out the key factors on which the customer service provider relationship depends in a service marketing scenario and the study identifies three underlying dimensions or key factors in this regard which are customers' loyalty \& commitment towards the service provider factor, consumers' satisfaction with their existing service provider factor and finally the consumers' trust towards their service provider factor [36]. So brand personality of a service brand should ensure customer satisfaction by highly differentiating the service brand, communicating the core values of the firm and its services internally and externally, building and maintaining emotional bonds with consumers and helping the consumer-brand relationships to develop.

So lastly from this discussion a conclusion can be drawn that CBBE Model for Banking sector should have two components i.e. Brand Awareness and customers' experience in terms of the six factors i.e. Service Operation, Employees, Environment, Features, Brand Aroused Feelings and Brand Personality.

\section{The CONCEPTUAL FrameWork For MEASURING CBBE} IN INDIAN BANKING SECTOR

Researchers of service marketing believe that consumers judge the quality of services based on their perceptions of the technical outcome provided or the end result of the process, the process through which that outcome is delivered and the quality of the physical surroundings where the services are delivered([37],[38],[39],[40]). Researchers also consider that the three new marketing mix elements (people, process and physical evidence) are included in the marketing mix as separate elements because they are within the control of the firm and because any or all of them may influence the customer's initial decision to purchase a service as well as the customer's level of satisfaction and repurchase decisions [20].

Recent empirical study on customer satisfaction in banking services in India has identified key factors of the extended Ps of services marketing i.e. People, Process and Physical Evidence on which the customer satisfaction depends [41]. According to this study the identified factors of 3Ps are as follows:

In terms of People (the $5^{\text {th }} \mathrm{P}$ )

i) Employees' knowledge about services factor. $\left(\mathrm{Pe}_{1}\right)$

ii) Employees' attitude and behaviour factor. $\left(\mathrm{Pe}_{2}\right)$

iii) Employees' service delivery efficiency factor. $\left(\mathrm{Pe}_{3}\right)$

In terms of Process (the $6^{\text {th }} \mathrm{P}$ )

i). Time saving factor. $\left(\operatorname{Pr}_{1}\right)$

ii). Convenience factor. $\left(\mathrm{Pr}_{2}\right)$

In terms of Physical Evidence (the $7^{\text {th }} \mathrm{P}$ )

i). Ambience and environmental conditions factor. $\left(\mathrm{Ph}_{1}\right)$

ii). Layout and functionality factor. $\left(\mathrm{Ph}_{2}\right)$

iii). Location factor. $\left(\mathrm{Ph}_{3}\right)$

Now in the theoretical linkage IV, the brand personality has been represented in terms of four main areas where it is relevant and these are relations, emotions, values and differentiation. 
As relationship again depends on customer satisfaction, relationship aspect of brand personality can be measured in terms of the eight factors of $3 \mathrm{Ps}$ i.e. $\mathrm{Pe}_{1}, \mathrm{Pe}_{2}, \mathrm{Pe}_{3}, \mathrm{Pr}_{1}, \mathrm{Pr}_{2}, \mathrm{Ph}_{1}, \mathrm{Ph}_{2}, \mathrm{Ph}_{3}$.

Again as emotion is particularly concerned with satisfying the customers by catering to their emotional needs, the emotional aspect of brand personality can be measured in terms of the eight factors of 3Ps i.e. $\mathrm{Pe}_{1}, \mathrm{Pe}_{2}, \mathrm{Pe}_{3}$, $\mathrm{Pr}_{1}, \mathrm{Pr}_{2}, \mathrm{Ph}_{1}, \mathrm{Ph}_{2}$, and $\mathrm{Ph}_{3}$.

Now as value is delivering and communicating values to the customers and differentiation is concerned with the uniqueness in service creation, operation and delivery, both of these aspects of brand personality can be measured in terms of the eight factors of $3 \mathrm{Ps}$ i.e. $\mathrm{Pe}_{1}, \mathrm{Pe}_{2}, \mathrm{Pe}_{3}, \mathrm{Pr}_{1}, \mathrm{Pr}_{2}, \mathrm{Ph}_{1}, \mathrm{Ph}_{2}, \mathrm{Ph}_{3}$.

Now in the CBBE model for banking services sector there are five other factors through which customer experiences can be depicted. The identified key factors of 3Ps can be linked with these five factors in the following way:

The $1^{\text {st }}$ Factor: Service Operation

In case of Service Operation, this factor is concerned with three dimensions of service quality i.e. Assurance, Responsiveness and Empathy. Again according to the recent research these three dimensions of services quality can be linked with the different factors of 3Ps [41].

Assurance is linked with i) Employees' knowledge about services factor. $\left(\mathrm{Pe}_{1}\right)$ and ii) Employees' attitude and behaviour factor. $\left(\mathrm{Pe}_{2}\right)$

Responsiveness is linked with i) Employees' knowledge about services factor.( $\left.\mathrm{Pe}_{1}\right)$ ii) Employees' attitude and behaviour factor.( $\left.\mathrm{Pe}_{2}\right)$ and iii) Employees' service delivery efficiency factor. $\left(\mathrm{Pe}_{3}\right)$

Empathy is linked with ii) Employees' attitude and behaviour factor. $\left(\mathrm{Pe}_{2}\right)$

\section{The $2^{\text {nd }}$ Factor: Employees}

The three identified factors of People i.e. i) Employees' knowledge about services factor. $\left(\mathrm{Pe}_{1}\right)$ ii) Employees' attitude and behaviour factor.( $\left.\mathrm{Pe}_{2}\right)$ and iii) Employees' service delivery efficiency factor. $\left(\mathrm{Pe}_{3}\right)$ can be linked with this $2^{\text {nd }}$ factor i.e. employees.

The $3^{\text {rd }}$ Factor: Environment.

Physical Evidence factors like i). Ambience and environmental conditions factor. ( $\left.\mathrm{Ph}_{1}\right)$ ii). Layout and functionality factor $\left(\mathrm{Ph}_{2}\right)$ can be linked with this $3^{\text {rd }}$ factor i.e. Environment.

The $4^{\text {th }}$ Factor: Features.

Physical Evidence factors like Location factor. $\left(\mathrm{Ph}_{3}\right)$ and Process factor like Convenience factor. $\left(\mathrm{Pr}_{2}\right)$ can be linked with this.

The $5^{\text {th }}$ Factor: Brand Aroused Feelings.

Physical Evidence factors like i). Ambience and environmental conditions factor. $\left(\mathrm{Ph}_{1}\right)$ ii). Layout and functionality factor $\left(\mathrm{Ph}_{2}\right)$ can be linked with this $5^{\text {th }}$ factor i.e. Brand Aroused Feelings.

Lastly the Brand Awareness component of the CBBE model which has two components i.e. Brand Recognition and Brand Recall can also be measured in terms of the identified eight factors of 3Ps.

So in this conceptual CBBE measurement model for banking services sector Brand Awareness and Brand Meaning in terms of the customer experiences can be measured using the different combinations of the eight factors of extended Ps of services marketing.

\section{LIMITATIONS \& FUTURE DiRECTIONS}

The conceptual framework developed in this paper proposes to measure brand equity in terms of eight identified factors of 3Ps of services marketing i.e. People, Process and Physical Evidence. Though the eight factors have been identified through empirical studies with customers' opinion regarding their level of satisfaction on banking services, the actual process of measuring customer based brand equity is a process of much complexity. Actual scale development requires rigorous statistical tests for checking the reliability and validity with empirical data. This conceptual framework will help future research by providing the platform for measuring customer based brand equity through eight factors of 3Ps.Scale items based on these eight factors can be constructed for future empirical research in order to build a measurement scale to measure customer based brand equity of banking services companies in India.

\section{CONCLUSION}

This paper attempts to make an integration of theoretical concepts by extensive literature review and lastly proposes a conceptual framework for measuring customer based brand equity for Indian banking services companies by convergence of the results of recent empirical research with existing available theoretical 
concepts in the literature.

\section{REFERENCES}

[1]. K.L. Keller, D.R. Lehmann, How do brands create value?, Marketing Management, 12(3), 2003, $26-31$.

[2] D. Aaker, Managing Brand Equity: Capitalizing on the Value of a Brand Name (New York, NY: The Free Press, 1996).

[3]. D. Aaker, Building Strong Brands (New York, NY: The Free Press, 1996).

[4]. K. L. Keller, Conceptualizing, Measuring, and Managing Customer-Based Brand Equity, Journal of Marketing, 57(1), 1993 , 1-22.

[5]. K. L. Keller, Brand Synthesis: The Multidimensionality of Brand Knowledge, Journal of Consumer Research, 29(4), 2003, 595600

[6]. T. Erdem, J. Swait, Brand equity as a signaling phenomenon, Journal of Consumer Psychology, 7(2), 1998, $131-157$.

[7]. J.Swait, T. Erdem, J.Louviere, and C. Dubelaar, The Equalization Price: A Consumer-Perceived Measure of Brand Equity, International Journal of Research in Marketing, 10(1), 1993, 23-45.

[8]. K. L. Keller, Strategic Brand Management Building Measuring \& Managing Brand Equity (New Delhi: Pearson Education, 2009).

[9]. D.A. Aaker, R. Jacobson, The Financial Information Content of Perceived Quality, Journal of Marketing Research, 31(2), 1994, 191-201.

[10]. D.A. Aaker, R. Jacobson, The Value Relevance of Brand Attitude in High-Technology Markets, Journal of Marketing Research, 38(4),2001,485-493.

[11]. L.L.Berry, Discovering the Soul of Service: The Nine Drivers of Sustainable Business Success (New York, NY: The Free Press, 1999).

[12]. L.L.Berry, Cultivating Service Brand Equity, Journal of the Academy of Marketing Science, 28(1), 2000,128 - 137

[13]. K.L. Keller, Strategic brand management: Building, measuring and managing brand equity (New Jersey, NJ: Prentice Hall, 1998).

[14]. D. Grace, A .O'Cass, Examining the Effects of Service Brand Communications on Brand Evaluation, Journal of Product and Brand Management, 14(2),2005,106-116.

[15]. M .Ghazizadeh, A.S. Besheli, V. Talebi, A Survey of Brand Equity and Customer Satisfaction of Iranian State-Owned Banks, European Journal of Social Sciences, 17(2),2010,266-273.

[16]. E.W.Anderson, Customer Satisfaction and Word of Mouth, Journal of Service Research, 1, 1998, 5 - 17.

[17]. A. O’Cass, D.A. Grace, Exploring consumer experiences with a service brand, Journal of Product \& Brand Management, 13(4), 2004, 257-268.

[18]. L .de Chernatony, R. Dall' O, Experts' views about defining services brands and the principles of service branding, Journal of Business Research, 46(2), 1999, 181 - 192

[19]. M.J.Bitner, Servicescapes: The Impact of Physical Surroundings and Customers and Employees, Journal of Marketing, 56(2), 1992, $57-71$

[20]. V.A. Zeithaml, D.D. Gremler, M.J. Bitner, and A. Pandit, Services Marketing: Integrating Customer Focus Across The Firm (New Delhi: Tata McGraw-Hill, 2008).

[21]. D. Padgett, D. Allen, Communicating experiences: A narrative approach to creating service brand image, Journal of Advertising, 26(4), 1997, $49-63$

[22]. M. L. Richins, Measuring emotions in the consumption experience, Journal of ConsumerResearch, 24(2), 1997, 127 -147.

[23]. J.S. Boles, B. J. Babin, T.G. Brashear, C. Brooks, An examination of the relationships between retail work environments, salesperson selling orientation-customer orientation and job performance, Journal of Marketing Theory and Practice, 9(3), 2001, 1 13.

[24]. R. Arora, C. Stoner, The effect of perceived service quality and name familiarity on the service selection decision, The Journal of Services Marketing, 10, 1996, 22-34.

[25]. J.A.Siguaw, A. Mattila, J. R Austin, The brand-personality scale, Cornell Hotel and Restaurant Administration Quarterly, 40(3), $1999,48-56$

[26]. J.L. Aaker, Dimensions of brand personality, Journal of Marketing Research, 34(3), 1997, 347-357.

[27]. M .Bosnjak, B .Rammstedt, T.L. Tuten, What does Aaker's brand personality scale actually measure? , Proc. Consumer Personality and Research Methods 2005 Conference, Dubrovnik, Croatia, 2005.

[28]. B.J. Thomas, P.C. Sekar, Measurement and Validity of Jennifer Aaker's Brand Personality Scale for Colgate Brand, VIKALPA, 33(3),2008,49-61.

[29]. N .Ghantous, 2008, Service branding for multiple stakeholders: A corporate personality perspective, Proc. The 18th International RESER Conference, Stuttgart, Germany, 2008.

[30]. L. de Chernatony, S. Drury, S. Segal-Horn, Building a services brand: stages, people and orientations, The Service Industries Journal, 23 (3), 2003, 1-21.

[31]. F. Dall'Olmo Riley, L.de Chernatony, The service brand as relationships builder, British Journal of Management, 11, 2000, 137150 .

[32]. S. Morrison, F. Crane, Building the service brand by creating and managing an emotional brand experience, Journal of Brand Management, 14 (5), 2007, 410-421.

[33]. B. Edvardsson, B. Enquist, M. Hay, Values-based service brands: narratives from IKEA, Managing Service, 16 (3), $2006,230-246$.

[34]. L. de Chernatony, S. Segal-Horn, The criteria for successful services brands, European Journal of Marketing, 37 (7/8), 2003, 10951118.

[35]. K. Kim, K.kim, D.kim, J.kim, S. kang (2008). Brand equity in hospital marketing, Journal of business research, 61, 2008, 75-82

[36]. D.Das, PREMASA Model: An Integrated Approach To Customer Relationship Management, IEM International Journal of Management \& Technology, 2(1), 2012, 111-118

[37]. C .Gronroos, A service Quality Model and its Marketing Implications, European Journal of Marketing,18(4),1984,36-44.

[38]. M.J.Bitner, Managing the Evidence of Service, in E. E. Scheuing and W.F.Christopher (Ed.), The Service Quality Handbook, (AMACOM,1993)358-370.

[39]. R.T. Rust, R.L. Oliver, 1994, Service Quality Insights and Managerial Implications from the Frontier, in R.T. Rust and R.L. Oliver (Ed.), Service Quality: New Directions in Theory and Practice, (California: Sage Publications, 1994)1-19.

[40]. M.K. Brady, J.J.Cronin, Some New Thoughts on Conceptualizing Perceived Service Quality: A Hierarchial Approach, Journal of Marketing, 65, 2001, 34-49.

[41]. D.Das, An Empirical Study To Build A Theoretical Framework That Can Determine Customer Satisfaction In Terms Of People, Process \& Physical Evidence, in S.Saibaba, A.Santikary and P.K.Mohanty (Ed.), Service Marketing Practices in India: Changing Paradigms, (Hyderabad : SSIM, 2012)135-143. 